\title{
Urban Ecosystems \\ Effects of garden management practices, by different types of gardeners, on human wellbeing and ecological and soil sustainability in Swiss cities \\ --Manuscript Draft--
}

Manuscript Number:

Full Title:

Article Type:

Keywords:

Corresponding Author:
UECO-D-17-00192R1

Effects of garden management practices, by different types of gardeners, on human wellbeing and ecological and soil sustainability in Swiss cities

\section{Manuscript}

Gardening; Wellbeing; Species richness; Soil quality; Management practices; Gardener typology.

Robert Home

Forschungsinstitut fur biologischen Landbau

Frick, SWITZERLAND

\section{Corresponding Author Secondary} Information:

Corresponding Author's Institution:

Forschungsinstitut fur biologischen Landbau

\section{Corresponding Author's Secondary} Institution:

\section{First Author:}

Robert Home

First Author Secondary Information:

Order of Authors:

$$
\begin{array}{|l|}
\hline \text { Robert Home } \\
\hline \text { Olivia Lewis } \\
\hline \text { Nicole Bauer } \\
\hline \text { Andreas Fliessbach } \\
\hline \text { David Frey } \\
\hline \text { Stéphanie Lichtsteiner } \\
\hline \text { Marco Moretti } \\
\hline \text { Simon Tresch } \\
\hline \text { Christopher Young } \\
\hline \text { Andrea Zanetta } \\
\hline \text { Matthias Stolze } \\
\hline
\end{array}
$$

\section{Order of Authors Secondary Information:}

Funding Information:

\section{Schweizerischer Nationalfonds zur} Förderung der Wissenschaftlichen

Forschung $(\mathrm{CH})$

(CRSII1_154416)

\section{Abstract:}

Gardens have effects on the local ecology as well as on the wellbeing of the gardener, but few studies have attempted to study gardens using both ecological and social outcome variables. The aim of this exploratory study is to address this research gap by identifying the characteristics of gardens and the management practices of gardeners that enhance the outcomes of gardening, which we separate into three dimensions: human wellbeing, biodiversity, and soil quality. Data were collected from 18 gardens in Zurich, Switzerland and a typology of gardeners was identified, which included 'conservationist', 'functional', 'minimum effort', 'child-friendly', and 'aesthetic' gardeners. The conservationist gardeners were found to have, on average, the highest species richness in their gardens, while the minimum effort gardeners had the lowest, which suggests that some degree of management can enhance species richness. The 
conservationist and minimum effort gardeners had, on average, the highest values for stable aggregates, while the minimum effort gardeners had the highest phosphorous content in their soil. The wellbeing of the minimum effort gardeners was lower than the other groups, which suggests it is the act of gardening, rather than merely having a garden, which leads to wellbeing outcomes. The results suggest that ecologically friendly gardening is compatible with desired social outcomes and furthermore that the beneficial effects of gardens are indeed related to the practices implemented by the gardeners, which are influenced by their attitudes towards gardening and the role of gardens in their lives. 
1 Authors: Robert Home ${ }^{* 1}$, Olivia Lewis ${ }^{1}$, Nicole Bauer ${ }^{2}$, Andreas Fliessbach ${ }^{1}$, David Frey ${ }^{2}$, 12 Stéphanie Lichtsteiner ${ }^{1}$, Marco Moretti ${ }^{2}$, Simon Tresch, ${ }^{1,2}$, Christopher Young ${ }^{2}$, Andrea $\begin{array}{lll}2 & 3 & \text { Zanetta }^{2} \text {, Matthias Stolze } \\ & \end{array}$

Title: Effects of garden management practices, by different types of gardeners, on human wellbeing and ecological and soil sustainability in Swiss cities

\section{Affiliations and addresses:}

1 Research Institute of Organic Agriculture (FiBL), Ackerstrasse 113, 5070 Frick, Switzerland

${ }^{2}$ Federal Research Institute for Forest Snow and Landscape Research (WSL), Zurcherstrasse 111, 8902 Birmensdorf, Switzerland

*Corresponding author:

Email address: robert.home@fibl.org

Telephone number: +41628657215 


\section{Introduction}

22 As the European urban population has increased, and urban planners have been

23 reluctant to allow urban sprawl, cities and towns have increased in density. This high-

24 density urban living means that urban green spaces are increasingly becoming 25 important nodes of contact with nature as well as providing nearby outdoor recreation 26 areas (Frick et al., 2007). The associated increase in demand for housing and 27 infrastructure puts pressure on these spaces, which are an attractive target for 28 development. Consequently, a growing number of European urban residents are 29 becoming increasingly disconnected from natural environments (Kiesling and Manning, 30 2010).

31 Despite the pressure from urbanization and densification of cities, urban green spaces 32 have persisted and contribute to the socio-ecological environment of a city through 33 direct and indirect social and environmental impacts (Drescher et al., 2006). Indeed, for 34 many people, urban green spaces, and especially gardens, provide their only, or at least 35 their primary, regular contact with the natural environment (Freeman et al., 2012). 36 Privately managed gardens are a particular type of urban green space in which the 37 gardener can create social and environmental outcomes from their activities. Such 38 gardens collectively account for a considerable proportion of urban green spaces in 39 most European countries (Van Heezik et al., 2013) including Switzerland (Lindemann40 Matthies and Marty, 2013).

41 Home et al. (2012) observed that there have been many studies of the social benefits of 42 urban green spaces, including gardens, and the almost universal opinion is that urban 43 green spaces contribute to the perceived quality of urban landscapes and to the quality 44 of life of urban residents. The sustainable management of urban green spaces and 
45

garden areas therefore can be regarded as crucial for achieving a resilient urban future

46 (Goddard et al., 2013). The agreement about the social benefits of urban nature has led

47 to recommendations that there should simply be more green spaces, with Sullivan et al.

48 (2004) suggesting that benefits for city residents would be maximised, and quality of life 49 enhanced, if there were nature at every doorstep.

50 In addition to social benefits, urban green spaces have also been shown to be of 51 ecological value. They support high biodiversity (Sattler et al., 2010), enhance ecosystem 52 functions, such as pollination (Hall et al., 2017), and provide a wide range of 53 environmental benefits (Ziter, 2016). Gardeners can influence the diversity and 54 abundance of plant and animal species by modifying the amount of habitats and 55 resources for wildlife in the gardens (Gaston et al. 2005) through their choices of how to 56 build and manage their gardens (Van Heezik et al., 2013). Provision of different habitat 57 patches and structural elements, such as hedges, woodpiles, or ponds, increases the 58 habitat variety and the attractiveness of garden areas (Davies et al., 2009). Smith et al. 59 (2006) found that human influence, in terms of management practices and the 60 installation of structural elements in the gardens, has a significant impact on species 61 abundance and richness in the gardens.

62 The importance of gardens, and of garden management, as contributors to the social and 63 ecological quality of urban environments suggests the value of gaining some 64 understanding of the interactions between social and ecological characteristics of 65 gardens. However, most studies have remained within disciplines, and few have 66 included both ecological and social variables (Van Heezik et al., 2013). The aim of this 67 study is to address this research gap by identifying the characteristics of gardens and 68 the management practices of gardeners that enhance the outcomes of gardening, which 69 we separate into three dimensions: human wellbeing, biodiversity, and soil quality. Once 
these characteristics and management practices have been identified, strategies can be

71 suggested to encourage garden management that enhances the quality of gardens.

72 Furthermore, strategies are likely to be more effective if they are tailored to the agent

73 who is intended to implement them, so an additional aim is to identify whether

74 particular types of garden managers exist.

\section{Typologies of gardeners}

There has been little multidimensional empirical research into urban gardens, so we chose a case study approach, which is a descriptive, exploratory or explanatory analysis of, in this instance, a selected set of gardens, that explores causation to find underlying principles (Yin, 2009). In this study, we focus on two types of privately managed gardens: Domestic gardens, which are usually next to people's houses; and allotment gardens, which are usually separate from houses, are organised into plots that are divided from a larger piece of land, and were primarily intended to provide a garden for those who would otherwise have no access to one. Van Heezik et al. (2014) pointed out that most studies of urban vegetation and ecosystem function have focussed only on vegetation in front gardens or on trees: mainly because of ease of visibility from the street. They further point out the value of examining whole gardens, with a focus on woody vegetation because of its contribution to ecosystem services and to habitats (Van Heezik et al., 2014).

Within urban gardens, there is a wide range of different gardening management approaches: Thompson (2007) distinguishes between conventional gardening management approaches and near-natural gardening and considers them as two ends of a gradient with a large variety of possibilities between the extremes. LindemannMatthies and Marty (2013) state that the majority of Swiss gardeners apply 
management practices that are towards the conventional end of the spectrum. These management approaches are presumably affected by the motivations of the gardener, as illustrated by Zagorski et al. (2004), who grouped gardeners into four attitudinal groups of: 'functional' gardeners, who commit significant time and work to creating a traditional gardenesque type garden, which is characterised by high degrees of management, large proportions of exotic plants, and geometrically shaped garden beds (Turner, 1986);

'conservationist' gardeners who aim for near-natural gardens; 'romantic' gardeners who value privacy and tend to create woody gardens; and 'minimum effort' gardeners who like gardens to create themselves, and preferred to minimize the activity of gardening. Kettle (2014) created a typology of five gardener types in Irish allotment gardens based on motivations: the 'Practical Gardener', the 'Idealist/Eco-Warrior', the 'Socio-Organic Gardener', the 'Gucci Gardener', and the 'Non-Gardening Gardener', and identified different gardening practices and structural differences in the gardens between types. The implication of these studies is that the motivations of the gardener influence which practices are chosen, which subsequently influences the characteristics of the garden and the social and environmental outcomes of the practices. There is, however, insufficient evidence in the literature as to whether these classifications are applicable in the Swiss context, so primary research is needed.

\section{Methodology}

The study was undertaken in two distinct phases. The first phase was to use Q-

methodology to identify latent groups within the sample and thus identify a typology of gardeners based on their attitudes towards gardens and gardening. The second phase was to examine the gardening outcomes from gardeners in the different latent groups. In this study, we follow the example given by Van Heezik et al. (2014), and include the 
whole garden, but expand the evaluation to include assessment of outcomes for

biodiversity and soil. Furthermore, we follow the suggestion of Goddard et al. (2013) to

include the perspectives of the gardeners. Specifically, the evaluated outcomes included:

garden practices, including which structural elements and habitat types had been

installed; the wellbeing of the gardener in relation to the gardening experience; plant

and arthropod species richness; and soil parameters. However, inclusion of several

dimensions of outcomes means that the study sites were subject to intensive

examination, which is also resource intensive. The available resources allowed a

relatively small sample size, so this study should be considered to be an exploratory case study.

\subsection{Sample}

129 The sample consisted of 18 gardens ( 9 allotments and 9 domestic gardens) in the city of 130 Zurich, Switzerland. Zurich is a medium sized, central European city with 410000

131 residents and is the centre of the largest metropolitan area of Switzerland, with 1.3

132 million residents. Domestic gardens, allotment gardens, and parks cover around 1500

133 ha, which is approximately 15\% of the city's administrative area (Gruen Stadt Zürich, 134 2010).

135 The selected gardens were all approximately $200 \mathrm{~m} 2$ in size, with variance in garden size 136 kept as low as possible to minimize a size effect. They were selected based on two main

137 factors that were expected to affect soil characteristics and biodiversity as well as 138 ecosystem services and underlying processes: the habitat heterogeneity (i.e. number of 139 habitat patches and structures) and management intensity (i.e. degree of disturbance) 140 within the gardens; and the surrounding landscape composition and configuration (i.e. gradient of urbanization). 


\subsection{Indicators of Outcomes}

5

6

7

8 9 10

To evaluate the outcomes of gardening practices, and thereby to address the aim of this study, indicators are needed. For the purposes of this study, we elected to evaluate the outcomes in three dimensions: social wellbeing, biodiversity, and soil quality.

Indicators of wellbeing were based on the results of Irvine et al. (2013), who identified a range of constructs, which they classified into seven domains, with which park users conceptualize green spaces as a resource for health and wellbeing. From this taxonomy, we created a 12-item scale, with items indicating the concepts (shown in table 1).

Table 1: About here

151 Indicators of biodiversity were based on species richness, which is often positively correlated with ecosystem functioning (Cardinale et al., 2012) and has been shown to be a useful biodiversity indicator in the cases of vascular plants (Van Heezik et al., 2014); ground dwelling arthropods (Braaker et al., 2014); and flying insects (Sattler et al., 2011). We are aware that use of three indicators gives only an approximation of overall complexity, of which there is certainly no straightforward way of measuring, but argue that this is acceptable in this exploratory study.

Indicators of soil quality should be able to readily show changes in soil conditions (Brejda et al., 2000), so we selected indicators of physical, chemical and biological properties, which are commonly used for holistic soil quality assessments (Karlen et al., 2008). Indicators that have proven useful in previous study are aggregate stability (Zornoza et al., 2015); phosphorous concentration (Haynes and Tregurtha, 1999); and microbial biomass carbon (Muscolo et al., 2015).

\subsection{Data collection and analysis}


The Q-methodology was applied by means of face to face interviews with the owner/manager of each of the sample gardens. Each participant was presented with a set of 33 or 30 statements (for allotment gardeners and domestic gardeners, respectively), and asked to sort them into a matrix with empty cells in roughly the shape of a normal distribution, according to their relative level of agreement with each statement. The $\mathrm{Q}$ data was organized into a correlation matrix, which was then used to perform a factor analysis. Q sorts that are highly correlated with one another may be considered to have a family resemblance (Brown 1996), which allows an identification of the latent "types" of gardener. The analysis was conducted using the program PQMethod, with varimax rotation.

75 Data on gardener wellbeing were gathered from garden owners by using a

questionnaire, which was mailed to the participating gardeners in May 2017. The questionnaire included a 12-item scale with one item for each of the indicators identified by Irvine et al. (2013). Participants responded to each question on a scale of 1-5, with 1 indicating "fully disagree" and 5 indicating "fully agree". An overall wellbeing index was also calculated for each gardener type: calculated as the sum of the unweighted averages of each of the above 12 indicators, and reduced to a scale of 1-5, with 5 indicating high wellbeing. This questionnaire also included questions about management practices and which landscape elements had been installed in the garden. Responses were received from 14 of the 18 gardeners, with the remainder indicating that they were incapable of completing the questionnaire due to age or illness.

Ground-dwelling arthropods were sampled using two triplets of 7-cm diameter pitfall traps placed in two of the most common garden habitat types, such as lawn, flower beds, vegetable beds and berry cultivations within each garden (Duelli et al. 1999). Flying insects were sampled using coloured pan traps, i.e. three 1-litre bowls (UV-bright blue, 
white, and yellow) fixed on a $1.5 \mathrm{~m}$ tall pole. Both pitfall and pan traps were filled with a $0.2 \%$ Rocima solution (a bactericide and fungicide from Acima, Buchs, Switzerland) and emptied on a weekly basis between May 18, 2015 and August 19, 2015, which covers the main activity season of most taxa (Obrist and Duelli 2010). In total, 20 taxonomic groups of arthropods representative of the main trophic levels and locomotion modes were sorted in the lab following standard procedures (Duelli et al. 1999), and identified to the species level. Plant species richness was assessed by two complementary methods: Two vegetation relevés of $10 \mathrm{~m} 2$ (in July) centred around pitfall trap sites; and a total garden flora inventory repeated three to four times in 2015 (early spring, spring, summer and early autumn).

Soils were sampled in March 2015 in the 18 selected gardens. Within the gardens, samples were taken near annual herbaceous plants (vegetables and flowers), which we regard as 'high disturbance'; and near perennial plants (berry cultures and lawn and perennial flowers), which we regard as 'low disturbance'. These paired samples were taken as a bulk sample of six soil cores from $0-20 \mathrm{~cm}$. Soils were sieved and dried or adjusted to soil moisture corresponding to $40-50 \%$ of the maximum water holding capacity. Bulk density was determined in undisturbed ring samples after drying at $105^{\circ} \mathrm{C}$. Soil organic carbon, $\mathrm{pH}$, and phosphorous content were analysed in dried soils. Soil microbial biomass was determined in moist samples. All analyses were done according to Swiss reference methods (Agroscope, 1996).

\section{Results}

\subsection{Gardener types}

The Q-methodology enabled the identification of five factors, with a total explained 213 variance of $77 \%$, and with all sorts accounted for by these factors. The statements that 
were used in the Q-sort, along with scores indicating where the statement is placed on a

\section{Table 2: About here}

The placement of each statement is shown by a number, ranging from +3 "I agree the most" to -3 "I agree the least", which indicates in which column of the representative matrix the statement falls. Each gardener type corresponds to a representative Q sort (i.e. statements placed into matrix in a way that represents the views of the type) and has been named. We adopted the same nomenclature for three of the groups identified in this study: 'conservationist', 'functional', and 'minimum effort' gardeners, as those given by Zagorksi et al. (2004) to three of their four 'attitude groups' because these groups closely mirrored each other in the two studies. We identified two further groups, which we call 'aesthetic' gardeners and 'child-friendly' gardeners. These names will be used throughout the presentation of the results.

Although standard Q-methodology encourages creating factors with two or more exemplars (a sort loading significantly on the factor), we chose to accept a factor with one exemplar because we suspect that child-friendly gardening is a shared orientation, but that our sample size was too small to capture more than one such gardener (see Watts and Stenner, 2005, on accepting one-factor exemplars). Descriptions of each type are as follows.

\section{Conservationist gardeners}

Of the 9 gardeners in this group, 7 are allotment gardeners and 2 are domestic gardeners. These gardeners are motivated by their belief that everything in nature is interconnected and interdependent. They get joy from having biodiversity in the garden and want to contribute to the preservation and promotion of biodiversity. They are also 
motivated by producing healthy food in the garden. They do not believe that pesticides and artificial fertilizers are necessary. Their practices are not motivated by the expectations of their neighbours nor because other gardeners do so. They are less concerned than others about having a lawn or having a neat garden.

\section{Functional gardeners}

Both of the gardeners in the second group are domestic gardeners. They choose their practices because they've had good experiences with them so far. They are convinced it is the right way to garden. They decide what to do in the garden because they like to learn about gardening, are happy to see biodiversity in the garden and find the garden beautiful to look at. They do not garden in a certain way because they learned it from their family or because they are trying to mimic other gardeners. They are not motivated to garden to produce healthy food in the garden or to harvest a lot of food. They are not motivated by worry about the consequences of artificial pesticides and fertilizers and believe more than other groups that the garden would not work if they stopped using these products.

\section{Minimum effort gardeners}

Of the 2 gardeners in the third group, both are domestic gardeners. These gardeners are motivated to garden in a way in which they do not have to put in a lot of physical exertion or pay big investment costs. They choose to keep gardening in the same way that they have always done. They like to have a neat garden and be a model for children through their gardening practices but they are not motivated to garden in a way that actively allows children to play in the garden without danger. They are more motivated than other groups to garden in a way that saves time. They do not choose gardening practices to meet their neighbours' expectations, because other gardeners 
recommended it to them or to get social recognition. They do not think the garden

\section{Child-friendly gardeners}

The gardener in the fourth group is a domestic gardener. (S)he is motivated to create a neat garden and to have a lawn. (S)he gardens in a certain way because (s)he is convinced that that's the right way. (S)he does not garden to learn about new gardening practices and implement the knowledge or to use practices recommended by other gardeners, mimic what other gardeners do, or replicate practices that were passed down in the family. (S)he gardens in his/her way because (s)he believes that it would not work without pesticides and artificial fertilizers. (S)he is more concerned than other groups with the ability for children to play in the garden without danger and is neither motivated by saving time in the garden nor enjoying the challenge provided by the way of gardening.

\section{Aesthetic gardeners}

Of the 4 gardeners in the fifth group, 3 are allotment gardeners and 1 is a domestic gardener. The aesthetic gardeners garden in a certain way because they want to contribute to preserving and promoting biodiversity, which they get joy from having in the garden. It is important to them to garden in a way that keeps the garden looking neat and beautiful. They use their practices because they have an inner conviction that it is the right way to garden. They are not motivated by having a lawn, by meeting the expectations of their neighbours, nor to harvest a lot of food. More than other groups, their practices are influenced by what they learned from their family and what other gardeners do. 
The results of the responses to the wellbeing indicators are presented, by gardener type, in figure 1.

\section{Figure 1: about here}

\subsection{Structural elements in gardens}

The number of gardens in which selected structural elements had been installed is shown in table 3.

Table 3: about here

\subsection{Biodiversity in gardens}

The results of the appraisal of the biodiversity indicators are shown in Table 4.

Table 4: about here

\subsection{Soil quality in gardens}

The results of the appraisal of the soil quality indicators are shown in Table 5.

Table 5: about here

\section{Discussion}

Zagorski et al.'s (2004, p.212) 'conservationist' gardeners were "distinguished from others by their devotion to habitat preservation, trees, native plants", so this name appears appropriate. The 'conservationist' gardeners group is similar to the 'idealist/eco-warrior' gardener type identified by Kettle (2014, p. 43), whose motivations "are part of wider concerns for the environment and ecological sustainability". The 'functional gardeners' group appears to be analogous to Zagorski et al.'s (2004, p.211) 'functional gardeners' who "are best discriminated from gardeners in other groups by their attachment to functionality (or practicality) and their pleasure in working with the garden". Zagorski et al.'s (2004, p.211) 'minimum effort' gardeners 
similarly liked gardens to create themselves and preferred to minimize the act of

gardening. We similarly identified a group of gardeners who are motivated to minimize physical exertion, investment costs, and time, and keep gardening in the same way they have always done. These are also similar to the 'non-gardening' gardeners identified by Kettle (2014).

'Child-friendly' gardeners, were not detected in the study of Zagorski et al. (2004) However, their distinguishing motivation (ability for children to play in the garden without danger) is similar to those of the 'non-gardening' gardeners observed by Kettle (2014, p.56), for whom the gardens "play an important social role for them, and in particular, their children [...they] place a high value on the social and pedagogic value of the allotment landscape". In contrast, Kettle (2014) observed the gardens appeared 'neglected or abandoned', whereas the 'child-friendly' gardener in our study placed high importance on keeping the garden neat and having a lawn. Further research, with a larger sample size, may support the idea of this group, potentially by investigating childfriendly features like sandpits as seen in the Irish 'non-gardening' gardens (Kettle, 2014). The 'child-friendly' gardener valued children being able to play safely in the garden, and therefore it is unsurprising that they had a lawn and flower beds but no other features, such as a water feature, free hedge, or dry stone wall, which could be potentially hazardous to playing children. The similarity of the 'child friendly' gardeners to the 'non-gardening' gardeners identified by Kettle (2014) suggest that the 'childfriendly' gardeners might be a subset of 'non-gardening' gardeners, but differentiated by their focus on children in the garden.

331 The 'aesthetic' gardeners have similarities to both Zagorski et al.'s (2004, p.211) 'romantic' gardeners who were "distinguished by their attachment to romance, sentimentality, privacy and space", by valuing aesthetics, and liking fauna/biodiversity 
in the garden; and to the 'Gucci gardeners' described by Kettle (2014), through focus on

certain design principles. The two groups contrast slightly: 'romantic' gardeners desire privacy and space, whereas 'Gucci' gardeners desire interaction and belonging, but also want to have a green space of their own. However, Kettle (2014, p. 53) describes the Gucci Gardeners as 'in all probability [...] a passing trend', but neither our results nor the results of Zagorski et al. (2004) indicate this, so the nomenclature of 'Gucci Gardeners' is not used; we also do not know if the 'aesthetic' gardeners in this study had a particularly romantic aesthetic, hence the more generalized name of 'aesthetic' gardeners.

The 'conservationist' gardeners were the only group to include water features in their gardens, although water features are commonly included in gardenesque type gardens (Turner, 1986) favoured by the functional gardeners. The 'conservationist' gardeners also commonly featured a wild area in their gardens, as did one of the 'minimum effort' gardeners. Interestingly, three of the four 'aesthetic' type gardeners also included a wild area, which suggests that there is an aesthetic appeal to wildness, which is in agreement with the results of Home et al. (2010) who found that cultivated wildness was considered attractive by Swiss residents. Neither 'functional' gardeners nor the 'child friendly' gardener cultivated vegetables in their garden, while one of the 'minimum effort' gardeners did cultivate vegetables, which was not expected. However, the finding that 'child friendly' gardeners did not cultivate vegetables further supports the hypothesis that 'child friendly' gardeners are a subset of Kettle's (2014) 'non-gardening' gardeners.

355 Generally, respondents indicated high levels of wellbeing across all indicators. However, 356 the overall wellbeing index for the 'minimum effort' gardeners (2.33) is much lower than that for the other gardener types (all $>4.20$ ). Although it cannot be statistically tested with a sample size of 14 , the results suggest that just having a garden does not in 
itself enhance well-being because, if that were the case, it could be expected that all

gardener types would have the same wellbeing outcomes. The results rather suggest

that it is the actual act of gardening: in which the 'minimum effort' gardeners are less involved in than the others, is important for increasing wellbeing. Conversely, the result might also be due to self-selection: If places other than the garden are better for enhancing the wellbeing of a 'minimum-effort' gardener, they will only invest minimum time and effort in the garden.

Biodiversity indicator results according to gardener type showed a pattern, indicating possible correlation between gardener type and biodiversity, which is likely mediated by management practices and variety in habitat types and structural elements: especially for plants and ground-dwelling species. The 'conservationist' gardeners had, on average, a higher variety of plants, ground dwelling arthropods and flying insects than the other groups. These gardeners also reported being highly motivated to promote and preserve biodiversity, and this may be reflected in the outcomes of their garden.

Interestingly, the 'minimum effort' gardeners, who do not focus on cultivation, (Kettle, 2014) had lower biodiversity than the 'conservationist' gardeners for all 3 indicators, and the lowest flying insect diversity of any group, which suggests that management can enhance biodiversity. These results fit with the Intermediate Disturbance Hypothesis (Catford et al., 2012), which suggests that both extremes of a management gradient (nomanagement and extreme intense management) lead to a reduction of available niches and thus to a lower number of coexisting species.

380 Gardens managed by the two 'functional' gardeners were remarkably similar in species 381 numbers of vascular plants and ground dwelling arthropods (mean=42.5), with the 382 latter similar in number to that found in the 'minimum effort' gardeners' gardens 
(mean=47). The Q-methodology revealed that these gardeners were not motivated by worry about the effects of pesticides and herbicides, although the minimum number of ground dwelling arthropods (28) in a 'conservationist' gardener's garden was found to be lower than the minimum found in either the 'minimum effort' (40) or 'functional' gardeners' (41) gardens.

The results show that 'conservationist' and 'minimum effort' gardeners had, on average, the highest values for stable aggregates, for which high values have several benefits for the soil functioning as detailed by Karlen et al. (2008). The high values for stable aggregates in gardens managed by 'minimum effort' gardeners can be explained because these gardeners either never, or no more than once a year, dig up their vegetable or flower beds or break up the soil there with a fork. However, all garden types had average stable aggregate values well above $65 \%$, the common value of top soil for no tillage systems stated by Beare et al. (1994), which indicates that soil structure is enhanced compared to agricultural sites: even within the groups who dig up or break up the soil more often.

398 The phosphorous levels were highest for 'minimum effort' gardeners. These levels suggest the addition of mineral fertilizer: especially in the minimum effort and aesthetic gardener groups. Soluble phosphorus contents were significantly higher in the disturbed areas, which suggest that they had received more fertilizers than the undisturbed areas such as lawn and berry cultures.

For all groups, the mean values of microbial biomass were between $600-900 \mathrm{mg} / \mathrm{kg}$, which is approximately equivalent to levels found in organic no-till systems (Karlen et al. 1994) and higher than in conventional Swiss agricultural soils (Krauss et al., 2017). The values were higher in the undisturbed garden areas, which may be explained by the 
higher rooting density and the perennial cover that permanently provides food

resources, such as rhizoexudates, to soil microorganisms and act as hot spots for

microbial activity in soils.

One of the main characteristics of urban soils is their relatively high variability and the patchiness of soil quality due to the high number of cultivated plant species and changes

in the soil types due to construction or land use history (Edmondson et al., 2014).

However, in the case of urban garden soils, gardening activities have the potential to improve soil quality significantly (Tresch et al., 2018). This may also be reflected in our data set in the relatively high values of soil stable aggregates and microbial biomass.

\section{Conclusions}

The case study gardens were quite intensively examined, with high demands on the participating gardeners due to multiple visits by ecologists and soil scientists along with lengthy interviews by sociologists, in what is, by definition, the private sphere of the garden owners. Although this study found several apparent links between attitudes towards gardening, management practices, and social, ecological and soil outcomes, the available resources did not allow a larger sample, and the reasonably small sample size makes generalizations difficult. It was also beyond the scope of this exploratory study to increase the number of interviews and consider other factors that potentially influence our indicators, such as demographics, the landscape composition (i.e. relative proportions of land-cover types) and configuration (i.e. spatial distribution of land cover types such as buildings, impervious areas, etc.) (Braaker et al. 2014). It will be the challenge for future research to consider these factors in encompassing studies with larger samples.

Despite these limitations, we were able to observe some patterns in the collected data.

430 The degree of wellbeing experienced by the responding gardeners did not appear to be 
related to gardener type with the exception of the minimum-effort gardener who reported an overall lower score on the wellbeing scale. This finding makes intuitive sense in light of the degree of control that the gardener has over the design and implementation of their gardens. Gardeners can make their gardens to suit themselves, and it appears that they each achieve some satisfaction with their results. The gardener who let the garden design itself also probably had a lower degree of engagement with the garden. This result suggests that it might be the act of gardening, rather than the ownership of the garden that leads to wellbeing.

The garden types did however appear to be related to the measures of biodiversity and soil quality. The most likely explanation for this connection is that the attitudes of the gardeners are reflected in the practices along with the garden elements that have been installed in the gardens. Indeed, the 'conservationist' gardeners tended to avoid pesticide use more, and to have a larger range of landscape elements, which provide a larger range of habitats, than did the other gardener types. Similarly, the garden types also appear to be related to the measures of soil quality. In this case, the 'conservationist' gardeners and the 'minimum effort' gardeners appear to enhance soil quality indicators, which appears to primarily reflect practices.

449 garden practices and the outcomes on biodiversity, soil, and human well-being. If these 450 links are established quantitatively, there are implications for city management who 451 may have an interest in encouraging practices they consider desirable. We have 452 attempted to measure the outcomes of practices on indicators in three dimensions; 453 however, we suspect interactions between the three dimensions might also occur. For example, the conservationist gardeners' gardens had the highest mean number of vascular plants and also the highest mean microbial biomass (Cmic), which raises the 
suspicion that there might be a relationship between them. However, this may also be due to the small sample size, so further study of a larger sample would be needed to confirm this suspicion.

The findings of this study suggest that the beneficial effects of gardens are indeed related to the practices implemented by the gardeners, which in turn appears to be influenced by the attitudes held by the gardeners. Gardeners design and implement practices in their gardens so that their gardens are how they like them. Gardeners with more positive attitudes towards nature were found to manage gardens with higher plant and animal species richness along with more favourable soil quality measurements. The challenge for ecologists seeking to enhance the ecological quality of urban domestic and allotment gardens will be to convince gardeners that ecologically friendly gardening is compatible with other desired social outcomes.

\section{Acknowledgements}

This research was funded by the Sinergia fund of the Swiss National Science Foundation. We are also grateful to the many students who assisted with the data collection and to the 18 gardeners who generously gave up their privacy by opening their gardens to the very many visits by researchers over the course of this project. The study was conducted in compliance with all relevant ethical requirements in Switzerland.

\section{List of references}

Agroscope (1996) Schweizerische Referenzmethoden der Eidgenössischen landwirtschaftlichen Forschungsanstalten. Eidg. Forschungsanstalt für Landwirtschaftlichen Pflanzenbau, FAP, 
Beare M, Hendrix P, Coleman D (1994) Water-stable aggregates and organic matter fractions in conventional-and no-tillage soils Soil Science Society of America Journal 58:777-786

Braaker S, Ghazoul J, Obrist M, Moretti M (2014) Habitat connectivity shapes urban arthropod communities: the key role of green roofs Ecology 95:1010-1021

Brejda JJ, Moorman TB, Smith JL, Karlen DL, Allan DL, Dao TH (2000) Distribution and variability of surface soil properties at a regional scale Soil Science Society of America Journal 64:974-982

Brown SR (1996) Q methodology and qualitative research Qualitative health research $6: 561-567$

Cardinale BJ, Duffy JE, Gonzalez A, Hooper DU, Perrings C, Venail P, Narwani A, Mace GM, Tilman D, Wardle DA, Kinzig AP, Daily GC, Loreau M, Grace JB, Larigauderie A, Srivastava DS, Naeem S (2012) Biodiversity loss and its impact on humanity Nature 486:59-67

Catford JA, Daehler CC, Murphy HT, Sheppard AW, Hardesty BD, Westcott DA, Rejmanek M, Bellingham PJ, Pergl J, Horvitz CC, Hulme PE (2012) The intermediate disturbance hypothesis and plant invasions: Implications for species richness and management Perspectives in Plant Ecology, Evolution and Systematics 14:231241

Davies ZG, Fuller RA, Loram A, Irvine KN, Sims V, Gaston KJ (2009) A national scale inventory of resource provision for biodiversity within domestic gardens Biological Conservation 142:761-771

Drescher A, Holmer R, Iaquinta D (2006) Urban homegardens and allotment gardens for sustainable livelihoods: management strategies and institutional environments. Tropical Homegardens, Springer, The Netherlands, pp 317-338 
Duelli P, Obrist MK, Schmatz DR (1999) Biodiversity evaluation in agricultural landscapes: above-ground insects Agriculture, Ecosystems \& Environment 74:3364

Edmondson JL, Davies ZG, Gaston KJ, Leake JR (2014) Urban cultivation in allotments maintains soil qualities adversely affected by conventional agriculture Journal of Applied Ecology 51:880-889

Freeman C, Dickinson KJ, Porter S, van Heezik Y (2012) “My garden is an expression of me": Exploring householders' relationships with their gardens Journal of Environmental Psychology 32:135-143

Frick J, Degenhardt B, Buchecker M (2007) Predicting local residents' use of nearby outdoor recreation areas through quality perceptions and recreational expectations For Snow Landsc Res 81:2

Gaston KJ, Warren PH, Thompson K, Smith RM (2005) Urban domestic gardens (IV): the extent of the resource and its associated features Biodiversity and conservation $14: 3327-3349$

Goddard MA, Dougill AJ, Benton TG (2013) Why garden for wildlife? Social and ecological drivers, motivations and barriers for biodiversity management in residential landscapes Ecological Economics 86:258-273

Gruen Stadt Zürich (2010), Biotoptypenkartierung der Stadt Zürich, https://www.stadtzuerich.ch/ted/de/index/gsz/planung_u_bau/inventare_und_grundlagen/naturschut z-inventar_und_kartierungen.secure.html

Hall DM, Camilo GR, Toniettto RK, Ollerton J, Ahrne K, Arduser M, Ascher JS, Baldock KCR, Fowler R, Frankie G, Goulson D, Gunnarsson B, Hanley ME, Jackson JI, Langellotto G, Lowenstein D, Minor ES, Philpott SM, Potts SG, Sirohi MH, Spevak 
EM, Stone GN, Threlfall CG (2017) The city as a refuge for insect pollinators Conservation Biology 31:24-29

Haynes R, Tregurtha R (1999) Effects of increasing periods under intensive arable vegetable production on biological, chemical and physical indices of soil quality Biology and Fertility of Soils 28:259-266

Home R, Bauer N, Hunziker M (2010) Cultural and biological determinants in the evaluation of urban green spaces Environment and Behavior 42:494-523

Home R, Hunziker M, Bauer N (2012) Psychosocial outcomes as motivations for visiting nearby urban green spaces Leisure Sciences 34:350-365

Irvine KN, Warber SL, Devine-Wright P, Gaston KJ (2013) Understanding urban green space as a health resource: A qualitative comparison of visit motivation and derived effects among park users in Sheffield, UK International journal of environmental research and public health 10:417-442

Karlen D, Wollenhaupt N, Erbach D, Berry E, Swan J, Eash N, Jordahl J (1994) Long-term tillage effects on soil quality Soil and Tillage Research 32:313-327

Karlen DL, Andrews SS, Wienhold BJ, Zobeck TM (2008) Soil quality assessment: past, present and future Journal of Integrative Biosciences 6:3-14

Kettle P (2014) Motivations for investing in allotment gardening in Dublin: a sociological analysis Irish Journal of Sociology 22:30-63

Kiesling FM, Manning CM (2010) How green is your thumb? Environmental gardening identity and ecological gardening practices Journal of Environmental Psychology $30: 315-327$

Krauss M, Krause H, Spangler S, Kandeler E, Behrens S, Kappler A, Maeder P, Gattinger A (2017) Tillage system affects fertilizer-induced nitrous oxide emissions Biology and Fertility of Soils 53:49-59 
Lindemann-Matthies P, Marty T (2013) Does ecological gardening increase species richness and aesthetic quality of a garden? Biological Conservation 159:37-44

Muscolo A, Settineri G, Attinà E (2015) Early warning indicators of changes in soil ecosystem functioning Ecological Indicators 48:542-549

Obrist M, Duelli P (2010) Rapid biodiversity assessment of arthropods for monitoring average local species richness and related ecosystem services Biodiversity and conservation 19:2201-2220

Sattler T, Duelli P, Obrist M, Arlettaz R, Moretti M (2010) Response of arthropod species richness and functional groups to urban habitat structure and management Landscape Ecology 25:941-954

Sattler T, Obrist MK, Duelli P, Moretti M (2011) Urban arthropod communities: Added value or just a blend of surrounding biodiversity? Landscape and Urban Planning $103: 347-361$

Smith RM, Warren PH, Thompson K, Gaston KJ (2006) Urban domestic gardens (VI): environmental correlates of invertebrate species richness Biodiversity and Conservation 15:2415-2438

Sullivan WC, Kuo FE, Depooter SF (2004) The fruit of urban nature: Vital neighborhood spaces Environment and Behavior 36:678-700

Thompson P (2007) The Self-sustaining Garden: The Guide to Matrix Planting. Timber Press,

Tresch S, Moretti M, Le Bayon R-C, Mäder P, Zanetta A, Frey D, Fliessbach A (2018). A Gardener's Influence on Urban Soil Quality. Frontiers in Environmental Science 6 Turner T (1986) English garden design: history and style since 1650. Antique Collectors' Club Ltd., 
van Heezik Y, Freeman C, Porter S, Dickinson K (2014) Native and exotic woody vegetation communities in domestic gardens in relation to social and environmental factors Ecology and Society 19

van Heezik Y, Freeman C, Porter S, Dickinson KJ (2013) Garden size, householder knowledge, and socio-economic status influence plant and bird diversity at the scale of individual gardens Ecosystems:1442-1454

Watts S, Stenner P (2005) Doing Q methodology: theory, method and interpretation Qualitative research in psychology 2:67-91

Yin RK (2009) Case Study Research: Design and Methods. SAGE Publications,

Zagorski T, Kirkpatrick J, Stratford E (2004) Gardens and the bush: gardeners' attitudes, garden types and invasives Geographical Research 42:207-220

Ziter C (2016) The biodiversity-ecosystem service relationship in urban areas: a quantitative review Oikos 125:761-768

Zornoza R, Acosta J, Bastida F, Domínguez S, Toledo D, Faz A (2015) Identification of sensitive indicators to assess the interrelationship between soil quality, management practices and human health Soil 1:173 
Table 1: Irvine et al.'s (2013) domains, with the corresponding statements and indicator names.

\begin{tabular}{|c|c|c|}
\hline Domain & Statement & Indicator name \\
\hline \multirow{3}{*}{$\begin{array}{l}\text { Physical } \\
\text { effects }\end{array}$} & When I work in the garden, I can let go and relax & Relaxed \\
\hline & My motivation to spend time in garden is to recover & Revitalized \\
\hline & $\begin{array}{l}\text { My motivation to spend time in garden is to get some } \\
\text { exercise }\end{array}$ & Exercise \\
\hline \multirow[t]{2}{*}{ Affective } & $\begin{array}{l}\text { My motivation to spend time in garden is to have a useful } \\
\text { activity }\end{array}$ & Useful activity \\
\hline & When I work in the garden, I can express myself & Express myself \\
\hline \multirow{2}{*}{$\begin{array}{l}\text { Place } \\
\text { attachment }\end{array}$} & I feel connected to my garden & Connected to garden \\
\hline & I feel at one with my garden & At one with garden \\
\hline \multirow{2}{*}{ Spiritual } & The garden is a change from my everyday & Change \\
\hline & I get feelings of satisfaction when I work in the garden & Satisfied \\
\hline \multirow{2}{*}{ Cognitive } & My garden is an escape from unwanted distractions & Escape distractions \\
\hline & It's easier to concentrate when I work in the garden & Attention restoration \\
\hline Social & $\begin{array}{l}\text { My motivation to spend time in garden is to spend time } \\
\text { with friends }\end{array}$ & Social \\
\hline
\end{tabular}


Table 2: Scores indicating where the statement is placed on a representative Q-sort for each of the 5 gardener types (from +3 "I agree the most" to -3 "I agree the least"

Statement: I cultivate and manage my garden the way I do

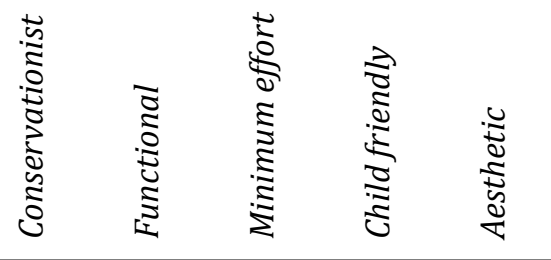

\begin{tabular}{|ll} 
because I can harvest more like this & -1 \\
because it means no large investment costs are necessary & -2 \\
because I can get direct environmental benefits like this (e.g. \\
pest control)
\end{tabular}

$-1 \quad-3$

$-2 \quad-1$

$-2$

$\begin{array}{rrrrr}+1 & -3 & -1 & 0 & -1\end{array}$

because I've had good experiences with it so far

because the garden is aesthetically beautiful to look at

because I have an inner conviction it's the right way

because this has been passed down in the family

because I want to produce healthy food in the garden

because I want to contribute to the preservation and promotion of biodiversity

because I want to conserve natural resources (e.g. water)

$\begin{array}{lllll}+1 & +3 & -1 & +1 & +1\end{array}$

because I worry about the consequences of pesticide use

because I like to have a neat garden

because I want to keep the soil fertile

because I am convinced everything in nature is

$\begin{array}{lllll}+1 & +3 & -1 & +1 & +1 \\ 0 & +2 & 0 & +1 & +2\end{array}$

interconnected and interdependent

because (my) children can play in the garden without danger $\begin{array}{llllll}0 & -2 & -3 & +3 & +1\end{array}$

because I like that it has a lawn

because my neighbours expect this from me

$\begin{array}{lllll}+1 & +3 & +1 & +2 & +3\end{array}$

because this brings me social recognition by the neighbours

because I want to be a model for (my) children

because I think that gardeners have an ecological

$-1-3$

$+2 \quad-3$

$+3 \quad 0 \quad+2 \quad+1 \quad+3$
responsibility

because other gardeners do so

$\begin{array}{ccccc}0 & 0 & 0 & -1 & 0 \\ +1 & -2 & 0 & 0 & -1 \\ -2 & +2 & +2 & +3 & +2 \\ +2 & 0 & -1 & 0 & +1 \\ +3 & +1 & 0 & -1 & +2\end{array}$

because this takes little time

because I like to learn about gardening and implement this knowledge

because this is very convenient

because it would not work without pesticides and artificial

fertilizers

because this takes little physical exertion

$\begin{array}{ccccc}-1 & +1 & +1 & +2 & -3 \\ -3 & 0 & -3 & -1 & -3\end{array}$

because I have always done it this way

because other gardeners recommended this to me

because I get joy from having biodiversity in the garden

$\begin{array}{lllll}-1 & -1 & -2 & -1 & 0\end{array}$

$\begin{array}{lllll}0 & -1 & +2 & -3 & 0\end{array}$

$\begin{array}{lllll}+2 & +1 & 1 & +2 & 0\end{array}$

because I enjoy the challenge that this system provides

$\begin{array}{ccccc}-3 & -2 & -2 & -2 & +1 \\ -2 & -1 & +2 & -2 & -1 \\ +2 & +2 & 0 & -3 & -1 \\ 0 & -1 & +1 & 1 & 0 \\ -3 & +1 & -3 & -2 & -2 \\ -2 & 0 & +3 & 0 & -2 \\ -1 & -1 & +3 & 0 & -2 \\ 0 & 0 & -2 & -3 & -1 \\ +3 & +3 & +1 & +2 & +3 \\ +1 & 1 & 0 & +3 & +2\end{array}$


Table 3: Number of respondents with each structural element in their garden: classified according to gardener type

\begin{tabular}{|l|c|c|c|c|c|}
\hline & $\begin{array}{c}\text { Conservationist } \\
(\mathrm{n}=9)\end{array}$ & $\begin{array}{c}\text { Functional } \\
(\mathrm{n}=2)\end{array}$ & $\begin{array}{c}\text { Minimum effort } \\
(\mathrm{n}=2)\end{array}$ & $\begin{array}{c}\text { Child-friendly } \\
(\mathrm{n}=1)\end{array}$ & $\begin{array}{c}\text { Aesthetic } \\
(\mathrm{n}=4)\end{array}$ \\
\hline Lawn & 5 & 2 & 1 & 1 & 0 \\
\hline Vegetable beds & 8 & 0 & 1 & 0 & 3 \\
\hline Flower beds & 8 & 2 & 1 & 1 & 4 \\
\hline Water feature & 5 & 0 & 0 & 0 & 0 \\
\hline Wild area & 7 & 0 & 1 & 0 & 3 \\
\hline Free hedge & 6 & 0 & 1 & 0 & 0 \\
\hline Dry stone wall & 3 & 1 & 0 & & 1 \\
\hline
\end{tabular}


Table 4: Biodiversity indicators per gardener type.

\begin{tabular}{|c|c|c|c|c|c|}
\hline \multicolumn{2}{|c|}{ Conservationist gardeners $(n=9)$} & \multirow{2}{*}{$\begin{array}{l}\text { Min } \\
75\end{array}$} & \multirow{2}{*}{$\begin{array}{l}\text { Max } \\
192\end{array}$} & \multirow{2}{*}{$\begin{array}{l}\text { Mean } \\
135\end{array}$} & \multirow{2}{*}{$\begin{array}{l}\text { Std.dev } \\
38\end{array}$} \\
\hline \multirow{3}{*}{ Biodiversity } & Vascular plants & & & & \\
\hline & Ground dwelling arthropods & 28 & 79 & 59.7 & 17.3 \\
\hline & Flying insects & 57 & 127 & 98.7 & 21.2 \\
\hline \multicolumn{2}{|c|}{ Functional gardeners $(n=2)$} & Min & Max & Mean & Std.dev \\
\hline \multirow{3}{*}{ Biodiversity } & Vascular plants & 102 & 110 & 106 & 5.7 \\
\hline & Ground dwelling arthropods & 41 & 44 & 42.5 & 2.1 \\
\hline & Flying insects & 60 & 102 & 81 & 29.7 \\
\hline \multicolumn{2}{|c|}{ Minimum effort gardeners $(n=2)$} & Min & Max & Mean & Std.dev \\
\hline \multirow{3}{*}{ Biodiversity } & Vascular plants & 68 & 114 & 91 & 32.5 \\
\hline & Ground dwelling arthropods & 40 & 54 & 47 & 9.9 \\
\hline & Flying insects & 54 & 74 & 64 & 14.1 \\
\hline \multicolumn{2}{|c|}{ Child-friendly gardeners $(n=1)$} & Value & & & \\
\hline \multirow{3}{*}{ Biodiversity } & Vascular plants & 71 & & & \\
\hline & Ground dwelling arthropods & 33 & & & \\
\hline & Flying insects & 83 & & & \\
\hline \multicolumn{2}{|c|}{ Aesthetic gardeners $(n=4)$} & Min & Max & Mean & Std.dev \\
\hline \multirow{3}{*}{ Biodiversity } & Vascular plants & 86 & 117 & 99.3 & 13 \\
\hline & Ground dwelling arthropods & 23 & 56 & 42.8 & 14.1 \\
\hline & Flying insects & 82 & 116 & 95.3 & 14.7 \\
\hline
\end{tabular}


Table 5: soil quality indicators per gardener type.

\begin{tabular}{|c|c|c|c|c|c|}
\hline \multicolumn{2}{|c|}{ Conservationist gardeners $(n=9)$} & \multirow{2}{*}{$\begin{array}{l}\text { Min } \\
64\end{array}$} & \multirow{2}{*}{$\begin{array}{l}\text { Max } \\
94\end{array}$} & \multirow{2}{*}{$\begin{array}{l}\text { Mean } \\
84.06\end{array}$} & \multirow{2}{*}{$\begin{array}{l}\text { Std.dev } \\
6.02\end{array}$} \\
\hline \multirow{3}{*}{ Soil quality } & Stable aggregate (\%) & & & & \\
\hline & Phosphorous (mg/kg) & 60.86 & 460.6 & 202.8 & 93.05 \\
\hline & $\begin{array}{l}\text { Microbial biomass (Cmic) } \\
(\mathrm{mg} / \mathrm{kg})\end{array}$ & 411.7 & 1343 & 861.8 & 207.63 \\
\hline \multicolumn{2}{|c|}{ Functional gardeners $(n=2)$} & Min & Max & Mean & Std.dev \\
\hline \multirow{3}{*}{ Soil quality } & Stable aggregate $(\%)$ & 59 & 93 & 81.75 & 8.13 \\
\hline & Phosphorous (mg/kg) & 66.51 & 196.1 & 119 & 29.60 \\
\hline & $\begin{array}{l}\text { Microbial biomass (Cmic) } \\
(\mathrm{mg} / \mathrm{kg})\end{array}$ & 279.9 & 1026 & 706.6 & 338.84 \\
\hline \multicolumn{2}{|c|}{ Minimum effort gardeners $(n=2)$} & Min & Max & Mean & Std.dev \\
\hline \multirow{3}{*}{ Soil quality } & Stable aggregate $(\%)$ & 75 & 92 & 85.75 & 6.72 \\
\hline & Phosphorous (mg/kg) & 168.3 & 465.2 & 305.2 & 118.84 \\
\hline & $\begin{array}{l}\text { Microbial biomass (Cmic) } \\
(\mathrm{mg} / \mathrm{kg})\end{array}$ & 468 & 862.8 & 684.6 & 27.18 \\
\hline \multicolumn{2}{|c|}{ Child-friendly gardeners $(n=1)$} & Value & & & \\
\hline \multirow{3}{*}{ Soil quality } & Stable aggregate (\%) & 80 & & & \\
\hline & Phosphorous (mg/kg) & 32.65 & & & \\
\hline & $\begin{array}{l}\text { Microbial biomass (Cmic) } \\
(\mathrm{mg} / \mathrm{kg})\end{array}$ & 846.8 & & & \\
\hline \multicolumn{2}{|c|}{ Aesthetic gardeners $(n=4)$} & Min & Max & Mean & Std.dev \\
\hline \multirow{3}{*}{ Soil quality } & Stable aggregate (\%) & 47 & 93 & 76.62 & 10.23 \\
\hline & Phosphorous (mg/kg) & 27.54 & 458.4 & 209.9 & 162.42 \\
\hline & $\begin{array}{l}\text { Microbial biomass (Cmic) } \\
(\mathrm{mg} / \mathrm{kg})\end{array}$ & 306.3 & 853.9 & 578.5 & 104.82 \\
\hline
\end{tabular}




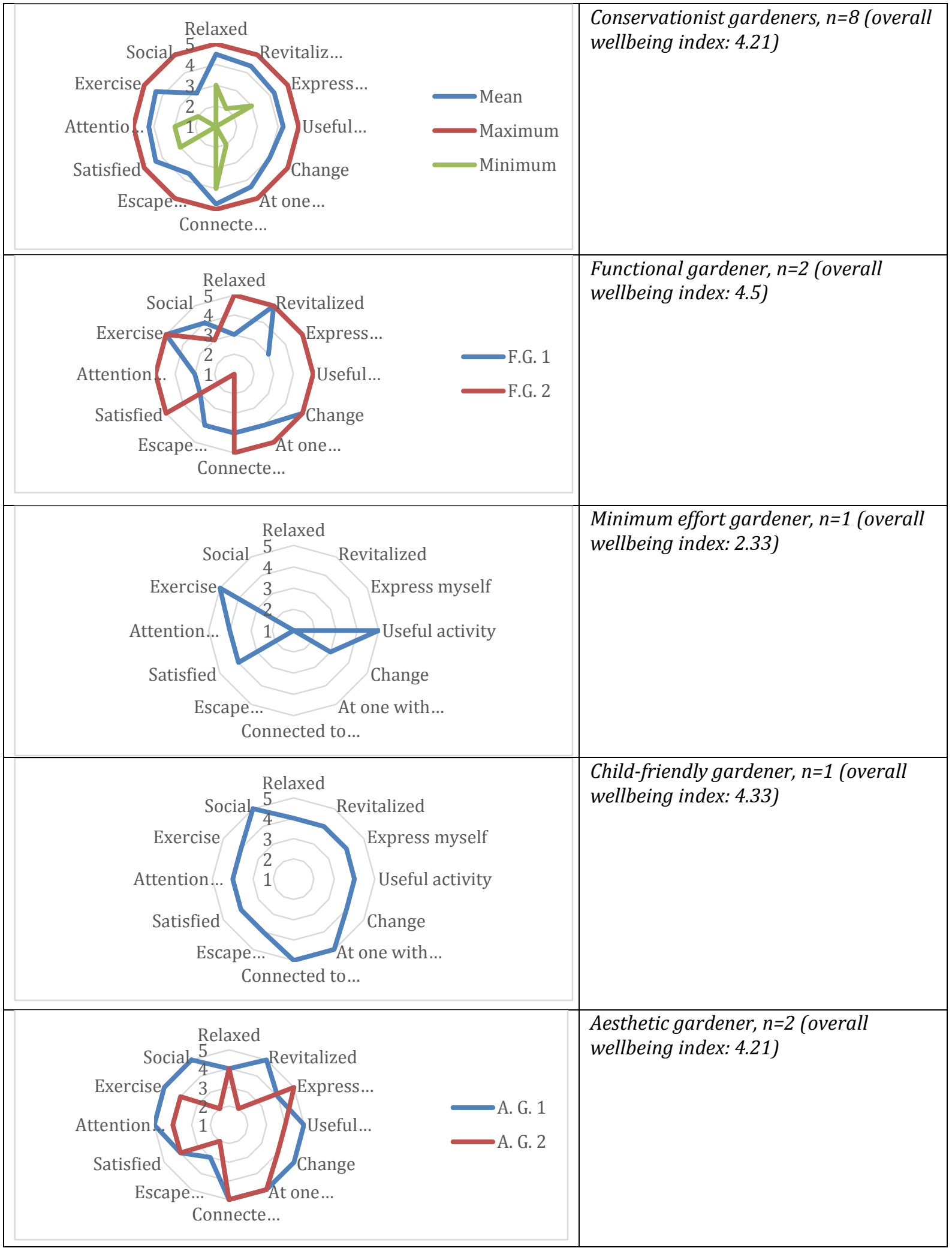

Figure 1. Well-being indicators for each gardener type 


\begin{tabular}{|c|c|}
\hline Comment & Response \\
\hline $\begin{array}{l}\text { Page } 3 \text { Line } 50 \text { - } 57 \text {. You state the aim of the } \\
\text { study here. However, everything from p. } 4 \text { Line } \\
17 \text { to p. } 9 \text { Line } 32 \text { is an extended discussion of } \\
\text { methods that you used in your study. This is } \\
\text { appropriate, however the } 5 \text { pages devoted to } \\
\text { this discussion is too much. You should } \\
\text { consider how to modify your introduction and } \\
\text { methods section so that the introduction has a } \\
\text { concise literature review and the methods } \\
\text { section covers the approaches you used in your } \\
\text { research. }\end{array}$ & $\begin{array}{l}\text { This is a fair point. In the submitted draft, we } \\
\text { included background information and } \\
\text { justification for selection of each of the } \\
\text { indicators, which we agree might have been } \\
\text { excessive. The excess text has been removed, } \\
\text { and the paper has been re-designed into a more } \\
\text { conventional format. }\end{array}$ \\
\hline $\begin{array}{l}\text { Page } 10 \text { Line } 17 . \text { Please explain what was } \\
\text { studied using Q-methodology. One way to do } \\
\text { this is to state what you want to determine } \\
\text { about gardeners before you describe the } \\
\text { analytical method. }\end{array}$ & $\begin{array}{l}\text { We've added the text in (new) line 115: "The } \\
\text { study was undertaken in two distinct phases. } \\
\text { The first phase was to use Q-methodology to } \\
\text { identify latent groups within the sample and } \\
\text { thus identify a typology of gardeners based on } \\
\text { their attitudes towards gardens and gardening". }\end{array}$ \\
\hline $\begin{array}{l}\text { In addition, some readers may wonder if Swiss } \\
\text { institutions require some type of consent } \\
\text { process before conducting research with } \\
\text { human subjects. If this is required please state } \\
\text { that your project was reviewed and approved. }\end{array}$ & $\begin{array}{l}\text { This is not a requirement in Switzerland. The } \\
\text { position of the Swiss Government is that } \\
\text { agreement to participate in an interview implies } \\
\text { consent to being interviewed. We added the } \\
\text { statement "The study was conducted in } \\
\text { compliance with all relevant ethical } \\
\text { requirements in Switzerland" In the } \\
\text { acknowledgements. }\end{array}$ \\
\hline $\begin{array}{l}\text { The combined results and discussion section is } \\
\text { somewhat difficult to follow. The descriptions } \\
\text { of the gardener types are very good. However it } \\
\text { is difficult to determine what you found for the } \\
\text { additional variables measured. Page } 18 \text { Line } 54 \\
\text { for example, only refers to a table and the } \\
\text { detail about what was found about biodiversity } \\
\text { is missing. Separating the results and discussion } \\
\text { sections would help. }\end{array}$ & $\begin{array}{l}\text { We have separated the results and discussion } \\
\text { sections, and we have taken care with internal } \\
\text { cross referencing. This restructuring has made } \\
\text { the text significantly easier to follow. }\end{array}$ \\
\hline $\begin{array}{l}\text { The statement numbers are confusing and may } \\
\text { explain why the reviewer felt that there were } \\
\text { missing citations. Including a data file with the } \\
\text { survey text would be helpful, and linking to } \\
\text { specific statements is not necessary. }\end{array}$ & $\begin{array}{l}\text { The statement numbers have been removed. } \\
\text { We believe it is reasonably clear what is being } \\
\text { referred to in the discussion. }\end{array}$ \\
\hline $\begin{array}{l}\text { The conclusions do not always support what is } \\
\text { written in the results section. For example, } \\
\text { there are statements about correlations among } \\
\text { environmental variables which are not found in } \\
\text { the data presented in the tables and figures. }\end{array}$ & $\begin{array}{l}\text { We have taken care to make sure that all } \\
\text { conclusions are justified by the results. We do } \\
\text { however raise questions about relationships } \\
\text { that we suspect may exist, but have added new } \\
\text { text to make it clear that the data is insufficient } \\
\text { to confirm the suspected relationships. }\end{array}$ \\
\hline $\begin{array}{l}\text { A major flaw that lends to speculation of } \\
\text { accuracy is the lack of proper citations. In } \\
\text { multiple instances, citations were missing from } \\
\text { statements within the manuscript. }\end{array}$ & $\begin{array}{l}\text { We have paid close attention to ensure that the } \\
\text { paper is correctly cited. }\end{array}$ \\
\hline $\begin{array}{l}\text { Of the } 84 \text { references, } 33 \text { were not cited within } \\
\text { the manuscript itself. This is a serious error and }\end{array}$ & $\begin{array}{l}\text { The superfluous references have been deleted } \\
\text { from the reference list. }\end{array}$ \\
\hline
\end{tabular}


